\title{
GMR
}

\section{Genetic variability in three populations of Hypostomus hermanni (Teleostei: Loricariidae) found in the basins of Ivaí River, Tietê River, and Sapucaí-Mirim River of Brazil}

\author{
R.S. Vieira and E. Renesto \\ Departamento de Agronomia, Programa de Genética e Melhoramento, \\ Universidade Estadual de Maringá, PR, Brasil \\ Corresponding author: R.S. Vieira \\ E-mail: rafabiologia@hotmail.com \\ Genet. Mol. Res. 15 (4): gmr15049056 \\ Received August 4, 2016 \\ Accepted October 4, 2016 \\ Published November 21, 2016 \\ DOI http://dx.doi.org/10.4238/gmr15049056
}

Copyright (C) 2016 The Authors. This is an open-access article distributed under the terms of the Creative Commons Attribution ShareAlike (CC BY-SA) 4.0 License.

\begin{abstract}
The genetic variability in three populations of Hypostomus hermanni from the tributaries of the rivers Ivaí (Keller), Tietê (Piracicaba), and Sapucaí (Sapucaí-Mirim) was determined using electrophoresis on starch gel. The variability in the genes for eight enzymes, namely, aspartate aminotransferase (EC 2.6.1.1), glucose-6phosphate isomerase (EC 5.3.1.9), glycerol-3-phosphate dehydrogenase (EC 1.1.1.8), isocitrate dehydrogenase (EC 1.1.1.42), L-lactate dehydrogenase (EC 1.1.1.27), malate dehydrogenase (EC 1.1.1.37), malate dehydrogenase NADP+ (EC 1.1.1.40), and phosphoglucomutase (EC 5.4.2.2), was assessed. Three loci with seven alleles were obtained in the population of Keller River whereas eight loci with 20 alleles and six loci with 16 alleles were present in the populations of Piracicaba and Sapucaí-Mirim rivers, respectively. Individuals analyzed in the
\end{abstract}


three watersheds presented all the detected polymorphic loci. The average heterozygosity was $0.0527,0.1742$, and 0.1299 in the Keller, Piracicaba, and Sapucaí-Mirim River populations, respectively. On the basis of identity values and genetic distances, all the three populations were determined to be genetically very similar.

Key words: Genetic variability; Hypostominae; Isoenzymes; Neotropical fishes

\section{INTRODUCTION}

The Neotropics (South and Central America) are considered the region of the greatest diversity of fish populations on the entire planet, with approximately 6000 of the 13,000 species of freshwater fish found here. Of these, 4475 species have already been described and it is estimated that probably 1550 species are yet to be described (Reis et al., 2003; Ferraris, 2007).

The order Siluriformes covers a broad and diverse group of fish distributed worldwide in the tropical regions (Burgess, 1989; Ferraris, 2007). The family Loricariidae consists of approximately 1000 species and only two-thirds of these have been described thus far (Reis et al., 2003). Fish belonging to the order Siluriformes have river-bottom habitat, with few exceptions. They exhibit a variety of shapes and sizes and are generally nocturnal (Ferraris, 2007). Some key features of species belonging to this order are body without scales, bony plates covering the body or bare skin, and rudimentary or developed barbels around the mouth (Nakatani et al., 2001).

The genus Hypostomus has some species with no clear status, mainly due to interspecies variation in morphology and their color patterns (Weber, 2003). Hypostomus is represented by fish that have several color shades, ranging from light to dark, with or without blemishes of various shapes and sizes, around the body (Armbruster, 2004).

Morphological differences may reflect genetic differences, some being very susceptible to the environmental influences. Furthermore, some populations are differentiated morphologically; they do not present reproductive isolation. In contrast, there are other forms without much morphological differentiation (Dobzhansky et al., 1977).

Molecular and biochemical markers such as isoenzymes can be used to phenotypically characterize an individual from samples of cells and tissues (Ferreira and Grattapaglia, 1998). Therefore, the objective of this study was to estimate the genetic variability in three populations of Hypostomus hermanni from three different river basins in Brazil, using the isoenzyme electrophoresis technique. We aimed to analyze the characteristics and evaluate the differences between individuals of the same species found at different locations, thus improving the understanding of the species.

\section{Siluriformes order}

The order Siluriformes consists of 36 families, which include about 478 genera, comprising approximately 3090 species (Ferraris, 2007); it is a well-diversified and widely distributed order. The representatives of this order popular in Brazil are catfish, mandis, jaús, pintados, among others. From an ecological perspective, instead of depending on their visual system, the members of Siluriformes have other sensory systems, such as well-developed

Genetics and Molecular Research 15 (4): gmr15049056 
and tactile olfactory organs and chemosensitive wattles. These features make these animals adapted to live in deeper waters, caves, aquifers, and confined spaces (Lundberg and Friel, 2003).

The Siluriformes mostly inhabit freshwater environments, with the exception of two families, Ariidae and Plotosidae, which comprise marine species. Their distribution seems to be limited by temperature because most of them inhabit the Tropics and Neotropics, and only a few reach the extreme south or the north end of the Americas (Nelson, 2006). The Siluriformes are usually found at the bottom of rivers, hiding among rocks and vegetation. The species of this order are sedentary and assume various sizes. They mostly do not move across waterfalls and rapids and, therefore, rarely migrate (Britski, 1981).

The family Loricariidae is the largest in the order Siluriformes and includes approximately $25 \%$ of the freshwater catfish in the world. Of the currently described species, 690 are distributed in the Neotropical regions from northern Costa Rica to the south of Argentina, and most of them are found in the east of the Andes (Reis et al., 2003).

H. hermanni is a loricariid species, inhabiting the upper Paraná River basin; it has a light-colored body, with a large dark spot (Weber, 2003). Previous analysis of isoenzymes, held in the Keller stream of a tributary on the right bank of the river Ivaí, revealed 25 loci with 35 alleles, in this species (Zawadzki et al., 2004).

\section{MATERIAL AND METHODS}

\section{Collection of specimens}

All the animals were collected in accordance with the guidelines of the Brazilian College of Animal Experimentation. The study was approved by the Research Ethics Committee of Universidade Estadual de Maringá. The specimens of Hypostomus used in this study were collected from Rio Grande basin, Paraná River basin, and basin of the Tietê River. The fish were captured in Ribeirão Keller, a tributary of Ivaí River (Figure 1); 34 samples were collected from $23^{\circ} 38^{\prime} 30^{\prime \prime} \mathrm{S} / 51^{\circ} 51^{\prime} 32^{\prime \prime} \mathrm{W}$, at $380 \mathrm{~m}$ in altitude, in the municipality of Marialva, Aquidaban district, State of Paraná. Another 34 specimens were caught in the Piracicaba river, a tributary of Tietê River (Figure 1) from $22^{\circ} 43^{\prime} 13^{\prime \prime} \mathrm{S} / 47^{\circ} 39^{\prime} 21^{\prime \prime} \mathrm{W}$, at $472 \mathrm{~m}$ in altitude in the city of Piracicaba, State of São Paulo.

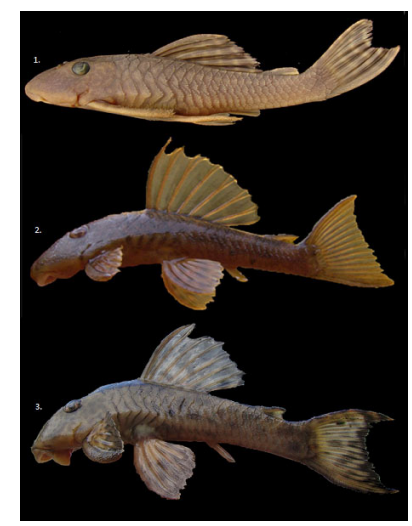

Figure 1. Hypostomus hermanni specimens collected from Sapucaí-Mirim River (1), Keller River (2) and Piracicaba River (3). The specimens are uncataloged.

Genetics and Molecular Research 15 (4): gmr15049056 
Thirty-one additional specimens were procured from Universidade Estadual Paulista, Botucatu campus; these were collected from the river in Rio Sapucaí-Mirim, a tributary of Rio Grande (Figure 1), located between $20^{\circ} 34^{\prime} 58^{\prime \prime} \mathrm{S} / 47^{\circ} 46^{\prime} 57^{\prime \prime} \mathrm{W}$, at $830 \mathrm{~m}$ in altitude in São Joaquim da Barra, State of São Paulo.

A total of 68 samples were collected from June 2013 to April 2014. All the H. hermanni specimens captured were included in the study; no exclusion criteria were used. The collected specimens were photographed (Figure 2) and subsequently stored intact in liquid nitrogen and transported to the laboratory number 21, H67 Block, Universidade Estadual de Maringá, and stored in a freezer at approximately $-20^{\circ} \mathrm{C}$ for extraction of enzymes at a later time.

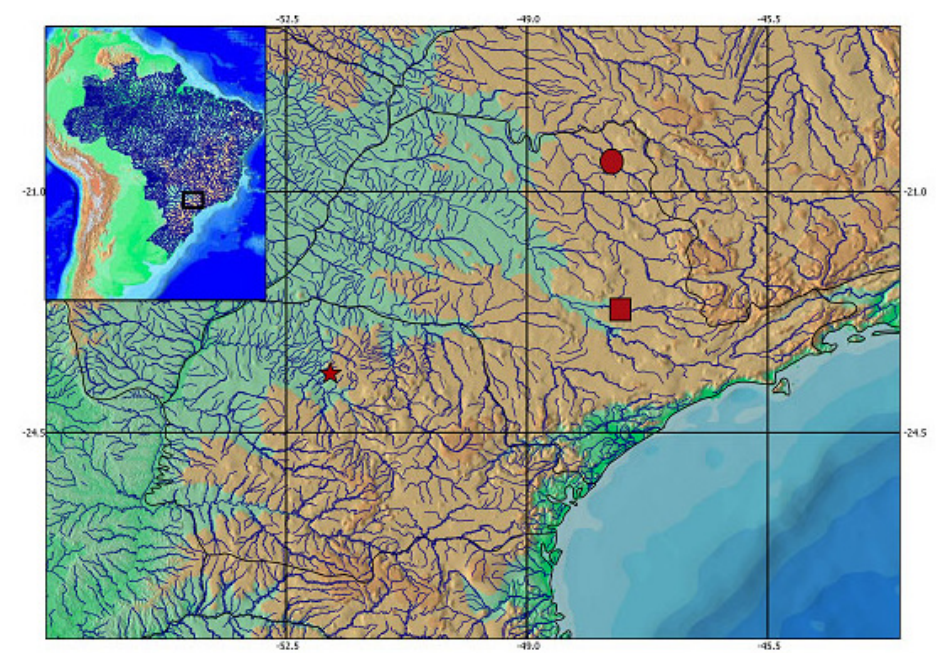

Figure 2. Hydrographic map of the States of São Paulo and Parana. The collection points for Hypostomus samples in Keller River (star), Piracicaba River (square), and Sapucaí-Mirim River (circle) are indicated by the red markers. The samples of muscle tissue were homogenized with a glass rod in polypropylene tubes $(1.5 \mathrm{~mL})$ with $100 \mu \mathrm{L}$ $0.02 \mathrm{M}$ Tris- $\mathrm{HCl}$ buffer, $\mathrm{pH} 7.5$. The protein extract was applied on a $15 \%$ corn starch gel (Penetrose 50; Val et al., 1981 ) with small strips of Whatman $3 \mathrm{MM}^{\circledR}$ filter paper $(4 \times 8 \mathrm{~mm})$, soaked in the samples. Continuous horizontal electrophoresis of the samples was performed under refrigeration. Two buffers used in the gel preparation were $0.135 \mathrm{M}$ Tris/0.043 M citric acid, $\mathrm{pH}$ 7.0, diluted 15 times and 0.18 M Tris/0.1 M Boric acid/EDTA 0.004 M, pH 8.6, diluted four times.

The electrophoresis was performed for about $15 \mathrm{~h}$ at a constant voltage of approximately $100 \mathrm{~V}$. After the electrophoresis, the gel was sliced horizontally into two, and the slices were incubated with specific histochemical solutions necessary for the development of an enzyme activity band for each system, prepared according to the protocol of Murphy et al. (1996).

The eight enzymatic systems analyzed by starch gel electrophoresis are reported in Table 1. The nomenclature of enzymes used was proposed by the International Union of Biochemistry and Molecular Biology (1992). The interpretation of genetic zymograms was based on the quaternary structure of the enzymes, according to Ward et al. (1992). Data were analyzed with Popgene 3.1 program. The genetic variability was estimated by calculation of the heterozygosity $\left(H_{\mathrm{E}}\right.$ and $\left.H_{\mathrm{O}}\right)$, according to Nei (1978). The values of allelic frequencies, the identity and genetic distance, of Nei (1978) were calculated, and a dendrogram of the studied populations was built (by the clustering method using the unweighted pair group method with arithmetic means algorithm). 


\section{RESULTS}

Using starch gel electrophoresis, eight enzyme systems (Table 1) from 99 individuals of $H$. hermanni were analyzed. Among these, 34 specimens were from the basin of the Ivaí river, 34 were from the Tietê river basin, and 31 were from the Rio Grande basin; eight loci were detected with 20 alleles in these specimens (Table 2).

Table 1. Name, international code of enzyme (EC), fabric, cap and quaternary structure (E.Q.) of the enzymes analyzed by starch gel electrophoresis.

\begin{tabular}{|c|c|c|c|c|}
\hline Enzyme (short) & EC Number & Tissue & Buffer & E. Q. \\
\hline Aspartate aminotransferase (AAT) & 2.6 .1 .1 & $\mathrm{M}$ & 1 & Dimeric \\
\hline Glycerol-3-phosphate dehydrogenase (G3PDH) & 1.1 .1 .8 & $\mathrm{M}$ & 1 & Dimeric \\
\hline Glucose-6-phosphate isomerase (GPI) & 5.3 .1 .9 & $\mathrm{M}$ & 2 & Dimeric \\
\hline Isocitrate dehydrogenase (IDH) & 1.1.1.41 & $\mathrm{M}$ & 2 & Dimeric \\
\hline L-lactate dehydrogenase (LDH) & 1.1.1.27 & $\mathrm{M}$ & 2 & Tetrameric \\
\hline Malate dehydrogenase (MDH) & 1.1.1.37 & M & 2 & Dimeric \\
\hline Malate dehydrogenase NADP + (ME) & 1.1.1.40 & M & 1 & Tetrameric \\
\hline Phosphoglucomutase (PGM) & 5.4 .2 .2 & $\mathrm{M}$ & 1 & Monomeric \\
\hline
\end{tabular}

$\mathrm{M}=$ muscle; 1 = Tris-borate-EDTA; 2 = Tris-citrate.

Table 2. Allele frequencies in the three populations of Hypostomus hermanni from the basins of the rivers Ivaí (river Keller), Tiete (Piracicaba River), and Sapucaí-Mirim.

\begin{tabular}{|c|c|c|c|c|}
\hline Loci & Alelles & Ivaí & Tietê & Sapucaí-Mirim \\
\hline \multirow[t]{2}{*}{$\overline{\text { Aat-1 }}$} & $A$ & 1.0000 & 1.0000 & 1.0000 \\
\hline & $A$ & 0.6875 & 0.1339 & 0.1625 \\
\hline \multirow[t]{2}{*}{ Aat-2 } & $B$ & 0.3125 & 0.8661 & 0.8250 \\
\hline & $C$ & & & 0.0125 \\
\hline G3pd & $A$ & 1.0000 & 1.0000 & 1.0000 \\
\hline \multirow{3}{*}{$G p i$} & $A$ & 1.0000 & 0.9688 & 1.0000 \\
\hline & $B$ & & 0.0312 & \\
\hline & $A$ & 0.0417 & 0.2778 & 0.2321 \\
\hline \multirow[t]{2}{*}{$\overline{I d h}$} & $B$ & 0.9583 & 0.7083 & 0.7679 \\
\hline & $C$ & & 0.0139 & \\
\hline \multirow[t]{3}{*}{$\overline{L d h}$} & $A$ & 1.0000 & 0.8800 & 1.0000 \\
\hline & $B$ & & 0.1200 & \\
\hline & $A$ & 1.0000 & 0.8400 & 0.8125 \\
\hline \multirow{3}{*}{$\overline{M d h-1}$} & $B$ & & & \\
\hline & $C$ & & 0.1600 & 0.1875 \\
\hline & $A$ & & & 0.0312 \\
\hline \multirow[t]{3}{*}{$\overline{M d h-2}$} & $B$ & 0.9688 & 0.7600 & 0.8438 \\
\hline & $C$ & 0.0312 & 0.2000 & 0.0938 \\
\hline & $D$ & & 0.0400 & 0.0312 \\
\hline$M e-1$ & & 1.0000 & 1.0000 & 1.0000 \\
\hline \multirow[t]{2}{*}{$M e-2$} & $A$ & & 0.0714 & 0.0500 \\
\hline & $B$ & 1.0000 & 0.9286 & 0.9500 \\
\hline \multirow[t]{2}{*}{$P g m$} & $A$ & & 0.1053 & 0.0417 \\
\hline & $B$ & 1.0000 & 0.8947 & 0.9583 \\
\hline
\end{tabular}

In H. hermanni from the basin of Ivaí river, 6 alleles distributed in 3 loci were detected; in the fish from the basin of Tietê river, 8 loci with 18 alleles were detected; and in those from Rio Grande basin, 6 loci with 15 alleles were detected. The allelic 
frequencies of the different locus in each species are shown in Table 2. The enzyme aspartate aminotransferase (AAT) showed two loci: Aat-1, encoding the positively charged enzyme and Aat-2, encoding the negatively charged enzyme. The Aat-1 locus was monomorphic for the three species. In the Aat-2 locus, three alleles were identified for individuals from Sapucaí-Mirim River; individuals from Ivaí and Piracicaba had two alleles each, all in Hardy-Weinberg equilibrium. In other fish species of the order Siluriformes, AAT enzyme was expressed by two (Zawadzki et al., 2004; de Paiva et al., 2005) and three alleles (Zawadzki et al., 1999), respectively.

In the glycerol-3-phosphate dehydrogenase enzyme system, the enzyme had a unique locus, and it was monomorphic for the three populations. In other species of Loricariidae, this enzyme was reported to have two monomorphic loci (Zawadzki et al., 1999, 2004; de Paiva et al., 2005).

For glucose-6-phosphate isomerase enzyme, only one monomorphic locus was detected in individuals of Sapucaí-Mirim and Ivaí; and a polymorphic locus, with two alleles was detected for individuals from Piracicaba River. The locus was in HardyWeinberg equilibrium. The enzyme isocitrate dehydrogenase (IDH) showed a single locus, with three polymorphic alleles for fish from Piracicaba River and two polymorphic alleles for specimens from Ivaí and Sapucaí-Mirim rivers. In a study conducted with Hypostomus specimens from Keller River, two loci for IDH and their variations were found (Zawadzki et al., 2004).

Only one locus was found in the L-lactate dehydrogenase enzyme. Individuals from Ivaí and Sapucaí-Mirim rivers were homozygous for the allele $A$. Individuals from Piracicaba River were polymorphic and had two alleles. Zawadzki et al. (2005), in a study of 15 Hypostomus species, found that this enzyme had two loci. The malate dehydrogenase (Mdh) enzyme was expressed from two loci: $M d h-1$ and $M d h-2 . M d h-1$ was monomorphic only in the specimen from Ivaí River. In specimens from Piracicaba and Sapucaí-Mirim rivers, it was polymorphic and had two alleles. $M d h-2$ was polymorphic in the three locations and had different number of alleles: two in specimens from Ivaí River, three in fish from Piracicaba River, and four in fish from Sapucaí-Mirim River. Other authors have report the presence of three loci for this enzyme in the fish of Loricariidae family (de Paiva et al., 2005; Zawadzki et al., 2005).

For the malate dehydrogenase NADP+ (ME) enzyme two loci, namely $\mathrm{Me}-1$ and $M e-2$ were found. $M e-1$ showed no changes in any of the populations. The Me-2 loci showed no variation in fish from Ivaí River, but those from Piracicaba and Sapucaí-Mirim rivers were polymorphic with two loci, each.

The isoenzymes of phosphoglucomutase (PGM) presented with a single locus. There was no polymorphism in the specimen from Ivaí River. In the specimens from Sapucaí-Mirim and Piracicaba rivers, two alleles of PGM were expressed and both were in Hardy-Weinberg equilibrium. These results corroborate with those from several other studies on fish that describe only one locus (for example, Renno et al., 1989).

A summary of the results of genetic variability in the three populations is shown in Table 3. The proportion of polymorphic loci in H. hermanni population from Ivaí River was $27.27 \%$ with three loci being polymorphic. The proportion of polymorphic loci was $72.73 \%$ in the samples from the Tiete River basin and $54.55 \%$ for fish from the SapucaíMirim River basin.

Genetics and Molecular Research 15 (4): gmr15049056 
Table 3. Measures of genetic variability in samples of Hypostomus hermanni in Keller and Ivaí River basin in the State of Paraná, Piracicaba, the Tiete River basin in the State of São Paulo, and Sapucaí-Mirim River basin in the State of São Paulo.

\begin{tabular}{l|c|c|c|c}
\hline Population & $H_{\mathrm{E}} \pm \mathrm{SD}$ & $H_{\mathrm{O}} \pm \mathrm{SD}$ & $\mathrm{P} \%$ & $\mathrm{~K} \pm \mathrm{SD}$ \\
\hline Keller & $0.0455 \pm 0.1508$ & $0.0527 \pm 0.1306$ & 27.27 & $0.33 \pm 0.4671$ \\
\hline Piracicaba & $0.1742 \pm 0.1511$ & $0.0322 \pm 0.0636$ & 72.73 & $0.40 \pm 0.7006$ \\
\hline Sapucaí-Mirim & $0.1299 \pm 0.1501$ & $0.0335 \pm 0.0764$ & 54.55 & $0.37 \pm 0.9816$ \\
\hline
\end{tabular}

$H_{\mathrm{E}}=$ expected heterozygosity; $H_{\mathrm{O}}=$ observed heterozygosity; $\mathrm{P} \%=$ proportion of polymorphic loci; $\mathrm{K}=$ number of alleles by loci; $\mathrm{SD}=$ standard deviation.

\section{DISCUSSION}

Using three Hypostomus populations from the Iguaçu River basin, Zawadzki et al. (1999) found that the percentage of polymorphic loci ranged from 20 to $40 \%$. In three species of Hypostomus from Maringa stream, de Paiva et al. (2005) detected 20\% polymorphic loci in Hypostomus strigaticeps and Hypostomus sp 1, but did not observe any polymorphism in Hypostomus sp 2.

Taking into account the same eight enzyme systems analyzed in this study, the mean $H_{\mathrm{E}}$ was 0.0527 in the population from Keller River, which was close to the average value of 0.051 , proposed by Ward et al. (1992) for fish species in general. For specimens from Piracicaba River, the average $H_{\mathrm{E}}$ obtained was higher and had a value of 0.1742 . In fish from Sapucaí-Mirim River, the value of $H_{\mathrm{E}}$ was 0.1299 , which was also higher than the average value estimated by Ward et al. (1992). These higher values of heterozygosity were expected in these two populations from São Paulo because of the fact that the species were collected from Piracicaba River where the species has been described and cataloged for the first time and the other place was geographically close to it. de Paiva et al. (2005) observed higher values for Hypostomus species, H. hermanni and $H$. albopunctatus, which ranged from 0.172 to 0.000 . In another study, Zawadzki et al. (2005) reported higher values of $H_{\mathrm{E}}$ for Loricariidae species from the Paraná River basin.

For some enzymes, same number of expressing alleles, as determined in this study, have been reported previously, indicating that besides having similar morphological characteristics, the expressed enzymes in the fish populations assessed are also similar, which makes it more difficult to differentiate between them. For other enzymes, differences in both the number of expressed alleles and the loci indicate that the populations are not as similar as they appear morphologically. The results of this study suggest that although already be in possession of some data on the species, to obtain a more accurate identification would be necessary to add other techniques, thereby improving the understanding of it. The results of the present study along with those reported by others form a good basis for establishing benchmarks between the species. The species with no commercial value or the ones that are not directly consumed by people as food, should nonetheless, interest the researchers because they might have important roles in maintaining the balance of the habitat and the in fostering relationships between the species. The advantage of such research would be that the maintenance of habitat would have a good effect, allowing further analysis involving more number of samples and, thereby, achieving more reliable results.

The identity and genetic distance values, standard Nei (1978), among the three species are shown in Table 4 . The data showed that the three species are genetically very similar. According to Thorpe and Solé-Cava (1994), the value of the genetic distance of

Genetics and Molecular Research 15 (4): gmr15049056 
three populations exceeds 0.85 , showing that the three populations are in Hardy-Weinberg equilibrium; this equilibrium was achieved because most of the loci were in equilibrium.

Table 4. Genetic identity values, standard Nei (above the diagonal) and genetic distance of Nei (below the diagonal) among the populations of Hypostomus hermanni in the three rivers, namely Keller, Piracicaba, and Sapucaí-Mirim.

\begin{tabular}{l|c|c|c}
\hline Population ID & Keller River & Piracicaba River & Sapucai-Mirim River \\
\hline Keller River & - & 0.9551 & 0.9653 \\
\hline Piracicaba River & 0.0459 & - & 0.9966 \\
\hline Sapucaí-Mirim River & 0.0353 & 0.0034 & - \\
\hline
\end{tabular}

The present study was conducted specifically with the enzymes in the muscle tissue because of the difficulty in extracting liver tissue from the specimens donated by Universidade Estadual Paulista. This was due to the conditioning time required for the whole frozen species, which caused the melting of some of the internal organs. Nonetheless, few analyses were performed using the liver samples collected from fishes procured from other locations; however, due to inconclusive results the data were discarded. In addition, the time for the completion of such work would not be enough and would require the use of limited resources, which ultimately might not give satisfactory results.

To ascertain the level of inbreeding and population structure, Wright (1965)'s F statistics, $F_{\mathrm{IS}}, F_{\mathrm{IT}}$, and $F_{\mathrm{ST}}$, were estimated for the three populations of $H$. hermanni. The $F_{\text {IT }}$ coefficient, which expresses the average rate of inbreeding, was 0.7408 . The $F_{\mathrm{ST}}$ values $(0.1194)$ are a measure of differentiation of the three populations based on the distance between them. According to Wright (1978), this value is between 0.05 and 0.15 , showing that the differentiation between the populations was moderate because five loci showed the percentages different of alleles.

Based on the data of genetic distances obtained, a dendrogram can be constructed that can be used for estimating genetic relationships among the species (Thorpe, and Solé-Cava, 1994). The dendrogram constructed using the unweighted pair-group method with arithmetic mean (UPGMA) method is shown in Figure 3. It shows that the three populations were grouped together, but the Keller River population was more distant from the others, probably due to reproductive isolation and geographical distance from the populations of Piracicaba and Sapucaí-Mirim rivers.

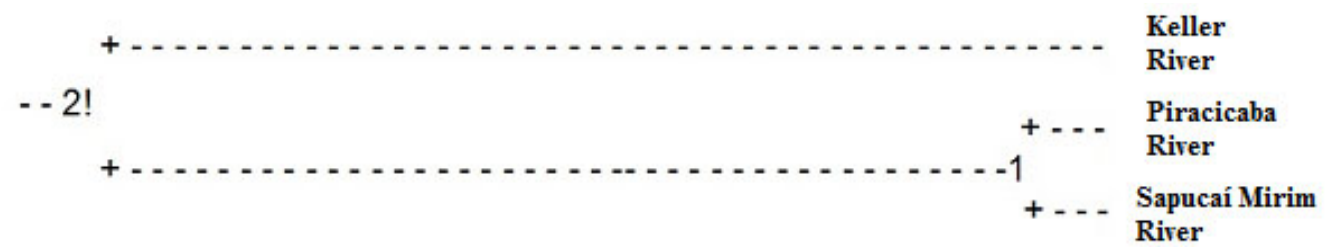

Figure 3. Dendrogram constructed using the UPGMA algorithm based on genetic distances of Nei (1978).

\section{CONCLUSIONS}

The analysis of eight enzyme systems using the isoenzyme electrophoresis technique allowed us to make the following conclusions: The genetic variability of $H$. hermanni populations from Piracicaba and Sapucaí-Mirim Rivers was considered to be above average

Genetics and Molecular Research 15 (4): gmr15049056 
than the variability of freshwater populations. The Keller River population had average variability that was close to the variability of freshwater populations.

The genetic identity values of Nei showed that the three populations were genetically very similar. However, the populations from Piracicaba and Sapucaí-Mirim River were very similar, probably due to their close geographic location.

\section{REFERENCES}

Armbruster JW (2004). Phylogenetic relationships of the suckermouth armoured catfishes (Loricariidae) with emphasis on the Hypostominae and Ancistrinae. Zool. J. Linn. Soc. 141: 1-80. http://dx.doi.org/10.1111/j.1096-3642.2004.00109.x

Britski HA (1981). Freshwater fish. In: Atlas of Brazilian fauna (Carvalho JCM, eds.). Improvement, São Paulo, 84-93.

Burgess WE (1989). An atlas of freshwater and marine catfishes. A preliminary survey of the Siluriformes. T.F.H. Publications, New Jersey.

de Paiva S, Renesto E and Zawadski CH (2005). Genetic variability of Hypostomus (Teleostei, Loricariidae) from the Ribeirão Maringá, a stream of the upper Rio Paraná basin, Brazil. Genet. Mol. Biol. 28: 370-375. http://dx.doi. org/10.1590/S1415-47572005000300005

Dobzhansky T, Ayala FJ, Stebbins GL and Valentine JW (1977). Evolution. W. H. Freeman and Company, San Francisco.

Ferraris CJ, Jr. (2007). Checklist of catfishes, recent and fossil (Osteichthyes: Siluriformes), and catalogue of siluriform primary types. Zootaxa 1418: 1-628.

Ferreira ME and Grattapaglia D (1998). Introduction to the use of molecular markers in genetic analysis. EmbrapaCenargem, Brasília.

Lundberg JG and Friel JP (2003). Siluriformes. Catfishes. Available at [http://tolweb.org/Siluriformes/15065/2003.01.20]. Accessed 14 April, 2015.

Murphy RW, Sites JW, Jr., Buth DG and Haufler CH (1996). Proteins: Isozyme electrophoresis. In: Molecular Systematics (Hillis DM, Moritz C and Mable BK, eds.). 2nd edn. Sinauer Associates, Massachusetts, 51-120.

Nakatani K, Agostinho AA, Baumgartner G, Bialetzki A, et al. (2001). Eggs and larvae of freshwater fish: development and identification manual. Eduem, Maringá.

Nei M (1978). Estimation of average heterozygosity and genetic distance from a small number of individuals. Genetics 89: $583-590$.

Nelson JS (2006). Fishes of the world. John Wiley and Sons, New York.

Reis RE, Kullander SO and Ferraris CJ (2003). Check list of the freshwater fishes of South America. Edipucrs, Porto Alegre.

Renno JF, Guyomard R, Boujard T and Bastide C (1989). Evidence for genetic isolation among four morphological species of Leporinus (Anostomidae, Pisces) in French Guiana. Living Resour. 2: 127-134. http://dx.doi.org/10.1051/alr:1989015

Thorpe JP and Solé-Cava AM (1994). The use of allozyme electrophoresis in invertebrate systematics. Zool. Scr. 23: 3-18. http://dx.doi.org/10.1111/j.1463-6409.1994.tb00368.x

Val AL, Schwantes AR, Schwantes MLB and De Luca PH (1981). Hydrolyzed corn starch as electrophoretic support. Sci. Cult. 33: 737-741.

Ward RD, Skibinski DOF and Woodwark M (1992). Protein heterozygosity, protein structure, and taxonomic differentiation. Evol. Biol. 26: 73-159.

Weber C (2003). Subfamily Hypostominae (Armored catfishes). In: Check list of the freshwater fishes of South and Central America (Reis RE, Kullander SO, Ferraris Jr. CJ, eds.). Edipucrs, Porto Alegre. 729.

Wright S (1965). The interpretation of population structure by F-statistics with special regard to systems of mating. Evolution 19: 395-420. http://dx.doi.org/10.2307/2406450

Wright S (1978). Evolution and the genetics of populations: Variability within and among natural populations. University of Chicago Press, Chicago.

Zawadzki CH, Renesto E and Bini LM (1999). Genetic and morphometric analysis of three species of the genus Hypostomus Lacépède, 1803 (Osteichthyes: Loricariidae) from the Rio Iguaçu basin (Brazil). Rev. Suisse Zool. 106: 91-105. http://dx.doi.org/10.5962/bhl.part.80072

Zawadzki CH, Renesto E, de Paiva S and Lara-Kamei MC (2004). Allozyme differentiation of four populations of Hypostomus (Teleostei: Loricariidae) from Ribeirão Keller, a small stream in the upper Rio Paraná basin, Brazil. Genetica 121: 251-257.http://dx.doi.org/10.1023/B:GENE.0000039852.65610.4f

Zawadzki CH, Renesto E, dos Reis RE, Moura MO, et al. (2005). Allozyme relationships in hypostomines (Teleostei: Loricariidae) from the Itaipu Reservoir, Upper Rio Paraná basin, Brazil. Genetica 123: 271-283. http://dx.doi. org/10.1007/s10709-004-5418-5

Genetics and Molecular Research 15 (4): gmr15049056 